\title{
A circulação de artefatos por meio das disposições testamentárias: apontamentos sobre as vestimentas na vila de São Paulo (1580-1640)
}

\section{Luciana da Silva ${ }^{1}$}

RESUMO: Com base no estudo de 179 testamentos e de 130 inventários, discutiremos alguns tópicos acerca da circulação de artefatos na vila de São Paulo, entre 1580 e 1640, focando as vestimentas. Partindo do pressuposto da importância das aparências no Antigo Regime, analisamos o trânsito dessa categoria de artefatos, estimulado pelas cláusulas testamentárias, na tentativa de compreender os sentidos atribuídos às peças e a sua movimentação. Para tanto, traçamos um quadro geral e resumido das vestimentas registradas nos patrimônios arrolados nos inventários, observando modelos e matérias primas de que eram feitas tais peças de roupa, bem como os valores atribuídos nas avaliações e o peso que esses elementos materiais da cultura representavam nos monte-mores paulistas. Em seguida, nos debruçamos sobre registros de últimas vontades que colocavam em circulação peças de roupas, observando os circuitos pelos quais passavam tais peças e os sentidos dessa circulação.

PALAVRAS-CHAVE: Cultura material. Vestimentas. Testamentos.

ABSTRACT: Based on the study of 179 wills and 130 inventories, we will discuss some topics about artifact's circulation in São Paulo village, from 1580 to 1640, concentrating in the garbs. Assuming the importance of the Old Regime appearances, we will analyze the transit related to this artifacts category, stimulated by testamentary clauses, to understand the meaning attribuited to the objects and their transit. Therefore, we did an overview fo the garbs registered in the enrolled assets in inventories, observing how the models and raw materials were made like the clothes, as well the assigned values in the ratings and the importance those materials elements of the culture represented in São Paulo's patrimonies. Then, we worked in the last records of wishes that put in transit garments, analyzing where these garments were and their meaning.

KEY-WORDS: Material culture. Garments. Wills.
1. Doutoranda - IFCH / Unicamp. E-mail: <lucipdg@ gmail.com>. 
2. Ver Raphael Bluteau (1728, v. 7, p. 386-387).

3. Cf. Id., (v. 8, p. 456-458).

4. Cf. Ibid., (p. 456). É importante ressaltar que Raphael Bluteau utiliza o espaço dessa definição para criticar a dissonância entre $\mathrm{o}$ exterior e o interior dos sujeitos. Para ele, as vestimentas deveriam corresponder ao estado da alma "não quer Deus que se misture o áspero do burel com o macio do linho, isto é, não querer, que com mimos, e regalos, se suavize a penitência, seria isso fazer uma monstruosa composição de vidas diferentes e estados incompatíveis", loc. cit.

5. Entre esses, ver Daniel Roche (2007) e Silvia Hunold Lara (2007, p. 79125).

6. Ver Ulpiano Toledo Bezerra de Meneses (2008, p. 12).

7. Id. (1983, p. 103-117).

8. Ver Ulpiano Toledo Bezerra de Meneses (1983, p. 112).

9. Ver Daniela Calanca (2008, p. 17-18).

10. Consideramos que a formação e a manutenção da sociedade na América portuguesa contou com elementos advindos do universo mental e cultural português, como por exemplo, uma noção de sociedade corporativa e de pacto político que vinculava soberano e vassalos na monarquia, de maneira a constituir hierarquias sociais com base nas lógicas de prestigio e etiqueta, entre outros elementos. Para aprofundar a discussão Ver João Fragoso e Maria de Fátima Gouvêa (2010, p. 1321).

11. Ver Philippe Ariès (1991, p. 9).
Introdução

Ao tratar da definição de roupa, Raphael Bluteau em seu Vocabulário, mencionou diversos significados, que de uma forma geral se relacionavam às vestimentas empregadas no corpo, ou aos artefatos de tecido usados na casa, como lençóis, toalhas, tapeçarias, etc. ${ }^{2}$ Ao definir vestido, o autor explica tratar-se de "o com que nos cobrimos, para a honestidade e para proteger o corpo das injurias do $a^{\prime \prime}$. . De maneira geral, percebe-se que "vestido" toma o sentido de conjunto de peças de roupas usadas para cobrir e proteger o corpo. Tais artefatos revestiam-se de outros significados, além dos práticos, quando pensados no contexto social. $\bigcirc$ clérigo regular aponta para essa dimensão em seu texto: "não há no mundo aparências mais enganosas, que as dos vestidos. Vestiduras eclesiásticas causam veneração, vestiduras militares imprimem terror; pomposas admiram, modestas edificam $[\ldots]^{\prime \prime} 4$.

As palavras registradas no Vocabulário permitem entrever uma questão interessante: as roupas tinham, aos olhos do religioso, a capacidade de acenar para a posição do indivíduo na sociedade, bem como de aguçar as sensibilidades e provocar diferentes reações naqueles que as observavam. A indumentária, enquanto artefato, era instrumento de distinção social no período em que o dicionário foi escrito, e conforme afirmaram diversos estudos históricos que tomaram essa categoria de elementos materiais da cultura como objeto de pesquisa ${ }^{5}$.

Concordamos com a asserção de Ulpiano Toledo Bezerra de Meneses, segundo a qual os artefatos expressam, moldam e em diversas gradações constituem os seres humanos ${ }^{b}$. Esses, que resultam das formas de organização do homem em sociedade, criam condições para que se produzam e se efetivem as relações sociais ${ }^{7}$. A cultura material, por sua vez, seria o segmento físico socialmente apropriado pelo homem, entendendo-se essa apropriação como a ação interventora e modeladora do homem em relação aos elementos do meio físico, de acordo com propósitos e normas culturais, ou seja, conforme padrões, entre os quais se encontram objetivos e projetos ${ }^{8}$.

De acordo com Daniela Calanca, que se dedicou ao estudo da história da moda na Itália, em sua longa duração (da Idade Média ao século XX), o vestuário, enquanto objeto de pesquisa, propicia um discurso histórico, econômico, etnológico e tecnológico, bem como funciona à maneira de um sistema de regras mais ou menos constante. As regras possibilitam que o revestimento do corpo assuma significados sociais codificados no tempo e pelo costume. Segundo a autora, roupas e adornos são meios pelos quais os corpos travam relações entre si e com o mundo externo. Vestir o corpo, conecta signos e sentidos 9 .

Acreditamos que em sociedades com características de Antigo Regime ${ }^{10}$, as roupas e acessórios contribuíam na definição da identidade do indivíduo, na sustentação de suas relações sociais, na amplitude de sua influência e prestigio, afinal, nesse contexto, parecer se confundia com ser ${ }^{11}$. Dessa forma, concordamos com as afirmações de Daniela Calanca sobre os trajes: a esses seria atribuída a importância 
de algo que permite conhecer o outro, o que apontaria para uma conexão entre indivíduo e sociedade. Isso porque a roupa diz respeito à pessoa como um todo - a todas as relações do sujeito com seu corpo e desse com a sociedade.

Muitos dos historiadores que se dedicaram ao estudo das vestimentas concordam que essas motivaram conflitos abertos e cerrados entre autoridades e grupos sociais, por conta dos aspectos simbólicos que sinalizavam posições sociais, em diversas épocas e regiões. Analisando a América portuguesa, Maria Beatriz Nizza da Silva observou a vestimenta enquanto elemento marcante no processo de adaptação e dominação de índios e negros, bem como elemento cultural que variava conforme grupos sociais, simbolizava funções e cargos, diversificava-se e refinava-se se adaptando as situações vivenciadas no espaço doméstico ou público ${ }^{12}$. Julita Scarano, focada na sociedade mineira setecentista, percebeu os usos que escravos e forros faziam das vestimentas para diferenciarem-se daqueles que preenchiam o rol dos miseráveis ${ }^{13}$. Beatriz Ricardina de Magalhães investigou as roupas enquanto componente da vida material que fugia ao âmbito da simples necessidade, sendo influenciado por fatores como moda, luxo, clima, hierarquias sociais entre outros ${ }^{14}$. As três autoras apontaram para a dimensão simbólica das roupas, reafirmando indiretamente a importância desses artefatos enquanto mediadores de relações sociais nas sociedades estudadas.

Tendo em vista a importância social e histórica das vestimentas como categoria de artefatos, debruçamo-nos sobre os indícios de sua circulação, registrados nos testamentos e inventários paulistas produzidos entre 1580 e 1640. Esse estudo integrou uma pesquisa mais ampla, na qual buscamos compreender aspectos das sociabilidades fomentadas pela circulação de artefatos e bens, bem como das sensibilidades envolvidas nesse trânsito. Cabe retomarmos alguns pontos fundamentais dessa pesquisa ${ }^{15}$.

Métodos e conceitos

Tomamos como hipótese geral a ideia de que a formação e a manutenção dos patrimônios materiais na vila de São Paulo, no período inicial da colonização (final do século XVI e início XVII), dependiam da inserção e do bom posicionamento do indivíduo em redes de sociabilidades, pelas quais circulavam objetos e bens, sendo estas redes condicionadas pela constante e intensa mobilidade. Os objetos e bens entendidos enquanto instrumentos simbólicos de comunicação, quando em posse de um indivíduo, definiriam visivelmente o lugar ocupado por esse na sociedade, contribuindo para seu reconhecimento e distinção no interior da comunidade. Nessa perspectiva, consideramos que os artefatos podem ser compreendidos como prolongamentos da ação e influência do indivíduo, permitindo a circulação desses elementos e sua infiltração em meios sociais diversos, mesmo em sua ausência. Isto se torna evidente no ato de legar, por meio do qual o testador, mesmo após sua morte, de certa maneira, mantém controle e influência sobre situações diversas.
12. Ver Maria Beatriz Nizza da Silva (1993, p. 227-241)

13. Ver Julita Scarano (1992, p. 51-61).

14. Ver Beatriz Ricardina de Magalhães (1997, p. 153199).

15. Realizada com o auxílio da FAPESP durante os anos de 2010 e 2012. 
16. Para este artigo, cremos ser relevante considerar a importância da União Ibérica como meio de dimensionar as conexões de São Paulo com outras regiões da América, apontando a ampla rede de contatos e, inclusive, relações comerciais que se firmavam a partir da vila e que depõem contra a ideia do isolamento piratiningano ao longo do século XVII. Entretanto, nosso foco são as relações de sociabilidades, especialmente as de familiares e vizinhança, intermediadas por artefatos no período. Sobre as conexões entre São Paulo e diversas partes da América espanhola, ver José Carlos Vilardaga (2010).

17. Compreendemos as sensibilidades da perspectiva de Sandra Jatahy Pesavento enquanto forma de apreensão e conhecimento do mundo, que emana do corpo em resposta a realidade, cuja esfera se situa num espaço anterior a reflexão. Ver Sandra Jatahy Pesavento (2007, p. 9-21).
O recorte cronológico adotado nesta pesquisa (1580-1 640) relacionase diretamente ao aumento das atividades sertanistas, pelo fato dessas contribuírem para a crescente presença do escravo indígena - elemento fundamental para o enriquecimento dos moradores de Piratininga e para o transporte de pessoas e cargas diversificadas nos caminhos que ligavam a vila ao litoral e outras paragens, concorrendo, dessa maneira, para tornar menos difícil o acesso a artefatos variados e de diferentes proveniências. Essas expedições constituem, também, o pano de fundo da pesquisa, já que submetiam o cotidiano dos habitantes da vila de São Paulo e arredores a uma constante mobilidade.

Cabe salientar também que o período escolhido foi marcado pela União Ibérica, na qual Portugal e suas possessões ao redor do globo permaneceram sob domínio do rei espanhol. Tal contexto político permite pensarmos São Paulo na órbita do império espanhol e no entroncamento de uma rede extensa de caminhos que permitiam a essa vila relacionar-se com diversos pontos no litoral, bem como no interior da América portuguesa, alcançando inclusive algumas regiões da América espanhola ${ }^{16}$.

Assim, selecionamos três formas de circulação de artefatos que lançassem luz sobre tais questões: as trocas comerciais com pagamentos a prazo, os empréstimos e as heranças. Todas as três eram constantemente registradas nos inventários e testamentos paulistas da época em questão, entretanto, neste artigo, focalizaremos apenas as heranças. Com base nessa documentação e apoio nas Cartas de Datas de Terra e nas Genealogias de Silva Leme e Pedro Taques, aproximamo-nos dessa circulação, percebendo as conexões firmadas e rompidas entre indivíduos com intermédio dos artefatos.

Impunha-se à pesquisa a necessidade de conhecer profundamente o universo material em questão, de maneira que pudéssemos perceber os artefatos em suas funções cotidianas e práticas, bem como sua dimensão simbólica. Para tanto, procedemos à leitura dos róis de bens dos inventários, separando os objetos em categorias diversas, buscando compreender seu uso e importância cotidiana por meio de dicionários de época e bibliografia especializada, principalmente. Com essas informações, procedemos à montagem de um banco de dados que nos permitiu realizar análises quantitativas e qualitativas dos artefatos presentes nos patrimônios paulistas do final do século XVI e primeira metade do XVII.

Pensar os artefatos em movimento implica observar seu trânsito, ou seja, verificar por que mãos passavam, bem como a relação ou circunstância mediada por este elemento material da cultura. É necessário, portanto, amplo conhecimento da sociedade e do cotidiano em questão. Assim optamos por nos aproximar dos domicílios paulistas, observando atentamente as relações familiares e de vizinhança nos indícios presentes nas fontes selecionadas, acima mencionadas. Ademais, tendo em vista as peculiaridades da documentação, as quais discutiremos mais a frente, especialmente os testamentos, é possível entrever indícios das sensibilidadess ${ }^{17}$ que marcavam os relacionamentos familiares e que se conectavam aos significados atribuídos aos artefatos e sua circulação nesse meio. 
De forma geral, de acordo com José María Imízcoz Beunza, o tecido de uma sociedade é composto pelos vínculos e redes de relações entre o indivíduo e o coletivo. E, numa sociedade com características de Antigo Regime, o vínculo social em si, bem como os diversos vínculos sociais, possuíam organização e consistiam em estruturações sociais reais. Tais conexões comportavam regras e práticas específicas, que dimensionavam o posicionamento das pessoas em funcionamentos coletivos determinados. Dessa maneira, a sociedade era marcada por um sistema de relações próprio, ou com características peculiares ${ }^{18}$. Nas palavras do autor: "o quadro social do Antigo Regime era um conjunto muito plural e complexo de corpos sociais ou comunidades e de vínculos pessoais e redes sociais. Todos eles tinham características específicas que se deve considerar na hora de analisar o funcionamento daquela sociedade"19.

Um primeiro nível das redes de relações na qual o indivíduo se imiscui seria composto pela família, enquanto teia de vínculos formados por consanguinidade e afinidade, teia essa que extravasaria o núcleo encontrado nos domicílios. Neste ponto, pensamos a família enquanto unidade produtiva e como um conjunto de parentes não residentes na mesma morada, ou um conjunto de coabitantes, os quais nem sempre possuíam vínculos de sangue ${ }^{20}$. Como apontou José María Imízcoz Beunza, consideramos também que nas sociedades de Antigo Regime os vínculos de família e parentesco tinham forte conteúdo social e poder estruturante, pois regiam a vida coletiva e a ação social dos indivíduos, condicionando sua vida pessoal. Dessa forma, relações afetivas, de dependência e comunidade de interesses somavam-se, pois os membros da família se apoiavam nas atividades comuns ${ }^{21}$.

Quanto às sensibilidades, é importante ressaltar que, enquanto forma de ser e estar no mundo, essas traduzem-se em sensações e emoções, mas correspondem também às manifestações do pensamento ou do espírito, por meio das quais a relação originária é organizada, interpretada e traduzida de maneira mais estável e contínua. As sensações transformam-se em sentimentos e afetos. Este seria o momento da percepção que "constrói um mundo qualificado, através de valores, emoções, julgamentos" 22. Dessa forma, as sensibilidades estariam no cerne do processo de representação do mundo.

As relações familiares e as sensibilidades por elas proporcionadas compõem um aspecto difícil de se apreender no estudo da vila de São Paulo entre o fim do século XVI e início do XVII. A documentação disponível oferece traços sobre a organização familiar, os quais precisam ser juntados e observados para além das lacunas: os inventários, reveladores dos modos de vida, apresentam, na maioria das vezes, a família nuclear, composta de pai, mãe e filhos. No entanto, havia também domicílios compostos por pai e filha, ambos viúvos, acompanhados de escravos, ou de homens sozinhos, entre outras situações. É necessário ler de forma atenta cada documento e cruzar as informações provenientes da leitura de conjuntos deles para descobrir os diversos arranjos familiares organizados nos domicílios.
18. Ver José María Imízcoz Beunza (1996, p. 13-50).

19. Cf. Ibid. (p. 19).

20. Ver Muriel Nazzari (2001) e Maria Beatriz Nizza da Silva (1984).

21. Ver José María Imízcoz Beunza (1996).

22. Cf. Sandra Jatahy Pesavento (2007, p. 13). 
23. Cf. Inventários e Testamentos... (v.12, p. 203).

24. Eduardo França Paiva, ao estudar os relatos testamentais de mulheres nas Minas Gerais setecentistas, realizou uma interessante análise sobre a produção desse documento. Esses relatos individuais comumente expressariam modos de viver e comportamentos coletivos, sendo documentos privilegiados para $o$ afloramento de símbolos, que introduziriam valores $\mathrm{e}$ modelariam comportamentos individuais e coletivos, compondo hábitos e costumes cotidianos, bem como posturas diante de diversos elementos da vida, inclusive a morte. Como o autor colocou, essa daria sentido ao registro testamental, pois muitos testadores produziam suas disposições testamentárias quando pressentiam o fim, "num momento em que a agonia do corpo e do espírito provocava alterações em seus sentimentos e em seu modo de viver". Ver Eduardo França Paiva (2009, p. 196).

25. Ver João José Reis (1991) e Cláudia Rodrigues (2005 e 1997).
Entretanto, cada inventário associado ao testamento de seu respectivo falecido pode revelar informações e pistas importantes acerca das relações familiares cotidianas. Vejamos um exemplo. Em 1638, quando faleceu, Pedro Martins morava na casa de sua filha viúva Maria Leoa. Seus pertences eram a roupa do corpo, umas botas de cordovão, um catre e uma caixa, duas peças forras e uma data de meia légua de terras "nos limites de Ibitoratim até o Juqueri a qual deixo as minhas netas Maria Montesserrate e Luzia de Ávila por boas obras que me fizeram e o dinheiro que comigo gastaram em minha doença o qual ganhavam por suas agulhas" 23

As terras deixadas para as netas concretizavam a gratidão pelo trabalho realizado em busca de dinheiro para tratar as doenças do avô. Pedro declarou em seu testamento que o sítio e casas em que morava eram de sua filha Maria e nada ali the pertencia. Todas as outras três filhas de Pedro já haviam falecido no ano de sua morte, restando-lhe como família a filha viúva, as netas e os netos filhos de Gaspar Manoel Salvago e sua outra filha, chamada Ana Ribeiro.

\section{Disposições de últimas vontades: o testamento}

Os testamentos são documentos muito úteis para o estudo das relações familiares, especialmente quando se objetiva analisar tais relações de maneira imbricada com a cultura material disponível no patrimônio dos indivíduos de outrora. Trata-se de documentos carregados de emoção, pois foram produzidos sob uma série de sentimentos, geralmente provocados pela proximidade da morte ${ }^{24}$. Estes revelam ao pesquisador, de maneira mais clara e direta do que nos inventários, as sensibilidades em relação à família e às coisas possuídas e que serão deixadas, além de apresentarem alguns traços da composição da vizinhança quando se observa e investiga os nomes das testemunhas que os assinaram.

Com forma e formalidades regulamentadas em lei e exigidas no momento de sua composição, os testamentos consistiam numa disposição solene de vontades na qual se definiam os desejos do testador referentes às providências a serem tomadas após sua morte, em relação ao seu corpo, alma e seus bens terrenos. Era um documento revogável, que dependia do cumprimento de todas as exigências estabelecidas pela lei no momento de sua feitura para a realização das disposições nele registradas, bem como era opcional.

Apesar de seu aspecto geral e função definidos pela legislação, os testamentos apresentavam forte caráter religioso, que se prendia aos ritos fúnebres e às crenças ligadas ao além ${ }^{25}$. Produzidos em contextos marcados por medos e crenças diante da morte, os testamentos integravam uma estratégia para salvação da alma: por meio deles, os indivíduos descarregavam suas culpas e faltas e proviam o bem para sua alma com doações, esmolas e pedidos de missas. Além disso, tentavam reorganizar a vida dos familiares que ficavam, ao menos materialmente, pela disposição dos bens terrenos. 
Da combinação de aspectos legais e religiosos derivava sua estrutura comum, que sofria algumas variações, perceptíveis quando se compara grande quantidade desses documentos ${ }^{26}$. Tal estrutura era organizada partindo-se da abertura, marcada geralmente por um preceito religioso, seguida da encomenda da alma, na qual se pedia auxílio a um santo protetor, das referências aos familiares, nas quais se encontram as declarações de herdeiros, testamenteiros, curadores dos órfãos, bem como, geralmente, arrolamento de alguns bens. Nas declarações sobre a terça, parte na qual o testador dispunha de um terço de seus bens da maneira que bem quisesse, encontram-se informações sobre objetos, quantias e destinatários. Em seguida têm-se as declarações das dívidas a cobrar e a pagar, a recomendação do cumprimento do testamento, a assinatura das testemunhas e a aprovação do tabelião.

Dentre todos esses campos informativos, interessaram-nos as declarações relativas à terça. Essa, considerada um espaço de vontades do testador, colocava em circulação artefatos e quantias em dinheiro, atribuindo a essa movimentação sentidos diversos. Por meio dessa circulação, é possível perceber preocupações e desejos concernentes à família e aos agregados, especialmente no que tange a prover melhoria ou estabilidade (mesmo provisória) das condições materiais de vida desses entes. $\bigcirc$ remanescente da terça, ou seja, a quantia que sobrasse de seu valor depois do pagamento das obras pias, era um mecanismo por meio do qual se poderia amparar aqueles que não herdariam nas partilhas, como no caso dos filhos bastardos. Vejamos alguns exemplos.

Em 1623, ao fazer seu testamento, Pedro Nunes declarava:

[...] tenho uma cadeia de ouro de $34 \$ 000$ [trinta e quatro mil réis], duas cruzes de ouro, e um par de pendentes e dois pares de cabacinhas, e três pares de arrecadas de três voltas cada uma, e uma gargantilha que tem seis folhinhas de ouro a modo de coração, e um jarro de prata, e sete colheres, e um garfo, e peço que se não tire de minha filha Maria cousa destas que não tenha outra o que se the dará a conta do remanescente da terça (...) e mando a meus herdeiros não entendam com as ditas coisas que dei a dita minha filha Maria, com pena de minha maldição, que tudo the dei em minha vida por ser minha única filha muito amada, para seu casamento e para ajuda de sua vida ${ }^{27}$.

As coisas legadas por Pedro à "filha amada" eram caras e parte delas havia pertencido à sua mãe, Catarina de Pontes, falecida em 1621. Na segunda parte do excerto, é possível notar o forte apego desse homem à sua herdeira, pois ele legou-the jóias e talheres de prata de altos valores. As coisas deixadas para Maria eram para o casamento e para ajudá-la em sua vida. Para Pedro era importante ampará-la e protegê-la, daí a ameaça aos outros herdeiros para não bulirem com sua herança. Ao final do inventário, em 1625, Maria, com apenas nove anos, tinha uma fortuna de duzentos e oitenta e nove mil réis, montante acentuado para a época, em que a maioria dos patrimônios somava monte-mores abaixo de duzentos mil réis.

Francisco Rodrigues Barbeiro, morador na vila de São Paulo, falecido em 1624, registrou em seu testamento, datado de 1623 o desejo de libertar e
26. Trabalhamos um total de 179 testamentos produzidos entre 1592 e 1640, os quais se encontram publicados.

27. Cf. Inventários $e$ Testamentos... (v. 6, p. 59). 
28. Cf. Inventários e Testamentos... (v. 6, p. 165).

29. Cf. Inventários $e$ Testamentos... (v. 6, p. 199212) garantir bom tratamento a sua filha bastarda Isabel, tida com uma índia, e de amparar materialmente sua neta Marta, filha de Isabel. Para a menina, reservou dote em sua terça e recomendou um tutor de sua confiança. Entretanto, quando das partilhas, a menina já era falecida e os bens que the eram destinados foram distribuídos igualmente entre os herdeiros legítimos de Francisco.

declaro que houve uma filha por nome Isabel de uma negra da terra minha a qual não é minha herdeira a deixo em sua liberdade como forra livre e isenta que é e querendo a dita Isabel depois de meu falecimento estar com alguma das ditas minhas filhas o poderá fazer pedindo a qualquer que em sua companhia a tiver the dê bom tratamento porque nisto hei por desencarregada minha alma declaro que esta dita minha filha Isabel bastarda acima dita tem uma filha por nome Marta a qual deixo de esmola vinte cruzados digo dez e assim The deixo mais a dita menina por nome Marta terá / digo chãos para uma casa os quais estão nesta vila para um lanço de casas [...] e declaro que isso deixo por esmola a dita menina para ajuda de seu casamento e o tomo em minha terça e os dez cruzados se the darão do melhor parado de minha fazenda os quais se entregarão a Aleixo Jorge e assim os chãos para que quando for tempo e a dita menina casar lh'os entregue e peço ao dito Aleixo Jorge que quando vier tempo tome a dita menina e a recolha em sua casa para que daí case e isto peço pelo amor de Deus ${ }^{28}$

As declarações de Francisco são bastante ilustrativas dos usos que eram feitos da terça para amparar parentes e agregados não beneficiados nas partilhas das heranças. Tomando certas quantias como esmolas, acertava-se que sua entrega seria garantida e fiscalizada pela justiça eclesiástica, pois os testamenteiros, entes encarregados do cumprimento do testamento, eram chamados a prestar contas perante a instituição. Dessa forma, as esmolas convertiam-se em mecanismos de ajuda, com finalidade caritativa, mas ao mesmo tempo, beneficiando pessoas que pela lei não herdariam. É possível, portanto, compreender as esmolas doadas às pessoas, observando-se atentamente as intenções desse ato donativo e seus beneficiários, enquanto dispositivo, no interior da terça, o qual fazia correr objetos, bens e quantias em dinheiro pelas redes de sociabilidades e pela sociedade no geral, estendendo a ação e influência do testador.

As esmolas, muitas vezes, consistiam em quantias em dinheiro, ou equivalentes, como pano de algodão, usado comumente enquanto moeda de troca na vila de São Paulo, ao longo do século XVII. Em alguns casos o auxílio era composto por peças de roupas. Às vezes o testador optava por doar gado por meio desse dispositivo. E em alguns casos, as esmolas consistiam em altos valores, compostos pela seleção de diversos objetos e bens, pois eram dirigidas a filhos ou netos bastardos, que não herdariam na fazenda do testador, como foi o caso de Francisco Rodrigues Barbeiro.

Maria da Gama, próxima de falecer em 1624, ao dispor de sua terça, definindo as esmolas, pediu que "o meu manto e saio e saia e calçado e gibão e toalha de cabeça e as minhas camisas deixo tudo de esmola a Inês mameluca que está em minha casa"29. Assim como determinado, Diogo Mendes, viúvo e testamenteiro de Maria, entregou os itens encomendados a João Paes, em cuja 
casa se encontrava a mameluca. De maneira semelhante, em 1615, Felipa Vicente deixava "de esmola a uma moça mameluca que tenho em casa dez cruzados chama-se Joana" 30 .

Muitos objetos e bens eram colocados em circulação por meio das últimas vontades estabelecidas em testamento. Assim, objetos e bens eram passados para familiares e amigos por meio da terça e de esmolas. Dessa forma, contemplavam-se entes queridos e, principalmente, programava-se e garantia-se a entrega de quinhões àqueles que não seriam beneficiados nas partilhas.

As vestimentas na vila de São Paulo.

No período estudado, uma categoria de bens destacou-se por circular intensamente por força das disposições testamentárias: as vestimentas. Por meio de esmolas ou das disposições da terça, davam-se peças dessa categoria, geralmente, a familiares e pessoas conhecidas. Essas doações eram marcadas por questões relativas ao posicionamento social dos indivíduos. As roupas eram legadas em testamentos de acordo com o que o recebedor representava na sociedade local: aos familiares mais próximos eram direcionados itens representativos de luxo e distinção, ao passo que aos escravos e agregados destinavam-se peças comuns, de algodão da terra. Essas decisões conectavam-se à importância com a qual as vestimentas eram revestidas na sociedade da vila de São Paulo.

Dessa forma, torna-se importante compreender as funções exercidas pelas roupas nessa região na primeira metade do século XVII, tendo em vista que esta era uma sociedade com características de Antigo Regime, a qual se instalava num ambiente repleto de peculiaridades e carestias, marcado ainda pelo intenso e renovador contato cultural com etnias diversificadas, mais fortemente a indígena, no momento estudado.

Traçaremos um quadro geral das roupas utilizadas no cotidiano e das peças luxuosas. Para tanto recorreremos à descrição dessas peças registradas nos inventários, contrastando-as com aquelas presentes em obras historiográficas sobre o tema do costume. Cremos que este seja um importante passo para que possamos pensar questões como origem das peças, materiais nelas empregados, entre outros, para analisarmos as avaliações que se faziam dessas vestimentas e de que maneira essas apontavam para os valores simbólicos que impregnavam esses artefatos na sociedade em questão.

Analisamos, para este estudo, uma amostra composta por 130 inventários redigidos em São Paulo entre 1596 e 1640. $\bigcirc$ critério para a seleção baseou-se na completude do documento: aqueles marcados pela ausência de trechos ilegíveis, ou que os tinha em quantidade pequena, de forma a não atrapalhar a leitura do rol de bens e partilhas. A partir dessa documentação observamos dados sobre a sociedade em questão e suas vestimentas: as peças de roupas mais comuns, para homens e mulheres, os tecidos mais comuns nessas peças, seus valores, entre outros. 
31. Cf. Alcântara Machado (2006, p. 94).

32. Ver Inventários $e$ Testamentos... (v. 12, p. 259294; v. 32, p. 102-112; v. 6 , p. 267-317; passim).

33. Ver Sérgio Buarque de Holanda (1994, p. 212).

34. Ver John French (1982, p. 104-105).

35. O ferragoulo era uma peça de roupa masculina, usada pelos portugueses do campo ou pescadores, que se parecia com o gibão, possuindo, entretanto, mangas curtas e uma pequena touca. Ver Raphael Bluteau (1712-1728, v. 2, p. 123-124).
Alcântara Machado, ao se debruçar sobre o vestuário dos "paulistas de antanho", constatou que no "desamparo e miséria da colônia", todos se vestiam "pobremente, por figurinos desuetos" 31 . Segundo o autor, o pano de algodão da terra, além de moeda corrente, era a matéria-prima principal das vestimentas dos colonos do planalto. Pela leitura dos inventários e testamentos, cremos que o historiador se cobria de razão.

O algodão, muitas vezes, era produzido no âmbito do quintal, como apontam os indícios de 11 inventários do período nos quais encontramos teares, algodoais, estoques de algodão, bem como pano de algodão pronto e mesmo índios tecedores. Em 1639 foi registrado no inventário de Francisco da Cunha Gago um tear com liças e pentes e setenta e cinco varas de pano de algodão. No de Maria Correia, datado de 1636, constava tear, bordadeira e três arrobas de algodão. No de Mathias de Oliveira, de 1628, havia dois teares e pano de algodão de velame grosso ${ }^{32}$. Sérgio Buarque de Holanda afirmou ser provável que o abastecimento desses produtos não dependesse apenas do cultivo local, sendo a carência compensada pela importação de outras capitanias e mesmo de fora da América portuguesa ${ }^{33}$.

Cabe salientar, entretanto, que o algodão paulista alcançava circuitos comerciais fora da capitania, conforme mostrou John French, por meio da figura de Domingos de Abreu, falecido em 1625, intermediário do comércio de longo alcance, que conectava São Paulo à Bahia, Rio de Janeiro e Pernambuco, a quem alguns moradores da vila vendiam o excedente ou sua produção de algodão, trigo, mandioca e carne, para posterior comercialização em outras paragens ${ }^{34}$.

No inventário feito por morte de Henrique da Cunha, no ano de 1624, constou na divisão dos bens entre os herdeiros que a João da Cunha, filho emancipado, caberia uma roça de mantimentos nova avaliada em quatro mil réis; um tear, em mil e duzentos réis; um mil novecentos e cinquenta réis em fios de algodão; vinte mãos de milho, em duzentos réis e mais um escravo tecelão indígena, não avaliado. Nota-se que todos os elementos necessários ao fabrico caseiro de tecidos de algodão estavam presentes no quinhão da herança que coube a João. Isso possibilitava-the produzir o tecido necessário para comerciar, mas, primeiramente, para suprir suas necessidades de roupas da casa e do corpo. Era comum o uso de pano de algodão na feitura de ambas, fosse cru ou tingido.

Quanto às roupas do corpo, as peças mais comumente feitas de algodão registradas nos inventários, de maneira geral, foram as camisas (para homens e mulheres) e as ceroulas (peça masculina). Entretanto, nas arcas e caixas de qualquer pessoa, grande variedade de outras peças, entre masculinas e femininas, advinha dessa matéria-prima. Roupetas, calções, gibões, ferragoulos ${ }^{35}$, saias, saios encontravam-se entre aquelas feitas do pano. Ou seja, possuir roupas de pano de algodão era comum em todos os grupos sociais, independentemente dos cabedais. Entretanto, ter roupas de tecidos refinados, trazidas do reino ou de outras paragens europeias, era privilégio de poucos. 
Apesar da grande maioria das vestimentas ser de algodão, existiam vestidos mais sofisticados, de tecidos diversos, provenientes de vários lugares. Como, por exemplo, a holanda (ou olanda), que seria "certa lençaria de várias castas", havendo olanda fina e "fina atacada, ordinária, grossa, riscada, e frisada, larga e olanda dita com seda", a qual, segundo Braudel, servia para fazer lençóis e roupa interior" ${ }^{36}$. Ou a baeta, que, segundo Raphael Bluteau, era "pano de lã a que, ou com o uso ou com instrumentos se levanta o pelo"37. As baetas poderiam ser identificadas por seu local de origem, como a baeta de Inglaterra, ou por seus diversos tipos: castelete, tecida com cinquenta e quatro fios, baeta de cosal, baeta de conta nova, baeta imperial, entre outros. Nos inventários estudados não há meios de identificar a presença dessa diversidade, pois os tecidos de baeta são descritos como tal, sem mais adjetivações.

Os derivados da seda eram recorrentemente empregados nas roupas mais caras e luxuosas. Por exemplo o damasco, tecido de seda com lavores, que recebera este nome por ser invenção original da cidade de Damasco, situada ao pé do Monte Líbano, mas que poderia apresentar variantes provenientes da Índia, da Itália ou de Castela ${ }^{38}$. Ou o tafetá, pano leve de seda que, de acordo com Bluteau recebe este nome "pela figura onomatopéia, do ruído tif taf que faz o que anda vestido desta seda" 39 . Este tecido fino, pelo que se observa nos inventários dos piratininganos, era utilizado mormente na confecção de saios, saias, calções, gibões e roupetas, ou seja, nas peças externas.

saio, segundo Raphael Bluteau, era algo como um "colete sem mangas [...] que vestindo-se nos braços não tem quartos dianteiros, e dos quartos traseiros pende uma cauda de quatro ou ao menos dois quartos até o chão"40. De acordo com a definição, os saios de dois quartos indicavam maior enfeite e os de quatro, maior modéstia. As mulheres nobres usavam esta peça, que cobria as costas somente com um bico para trás, chegando, na frente até a altura da cintura, com mangas abertas até o punho, algumas com um bolso no cotovelo. No caso das mulheres do povo, o saio era como um casacão e as mangas eram do mesmo feitio.

Item do traje masculino, os calções cobriam o corpo dos homens da cintura até os joelhos. Os registros nos inventários não eram detalhados, constando apenas os tecidos de que eram feitos e as cores. $\bigcirc$ único tipo especificado em alguns documentos foi calções golpeados, terminologia que indicava uma certa confecção na qual são feitas aberturas no tecido para que o forro apareça e dê volume à peça ${ }^{41}$.

gibão ${ }^{42}$, por sua vez, estava presente nas vestimentas de homens e mulheres. Esse cobria o tórax, da altura do pescoço até a cintura e era usado por cima da camisa (vestidas por homens e por mulheres). Já as roupetas ${ }^{43}$ consistiam em casacas curtas, que eram usadas sem capa pelos homens.

As peças mais comuns do vestuário da vila de São Paulo eram a camisa, as ceroulas, os calções, a roupeta, o gibão, as meias e ferragoulos para os homens e a camisa, a saia, o saio e o gibão para as mulheres. Entretanto, cabe frisar,
36. Cf. Fernand Braudel (1995, v. 1, p. 289).

37. Cf. Raphael Bluteau (1712-1728, v. 2, p. 11).

38. Id. (1712-1728, v. 3, p. 6)

39. Cf. Ibid. (v. 8, p. 15).

40. Id.(v. 7, p. 518)

41. Ver Raphael Bluteau (1712-1728, v.2 p. 52).

42. Ibid. (v.4, p. 69).

43. Ibid. (v.7, p.387). 
44. Ver John French (1982, p. 98-99).

45. Ver Inventários $e$ testamentos ... (v. 8, p. 2390).

46. De acordo com Bluteau era o "natural de Biscaya", província dividida entre Castela e França. Ver Raphael Bluteau (v. 2. p. 127).

47. Ver Inventários $e$ testamentos... (v. 5, p. 109130).

48. Cortina da cama ou leito. Ver Raphael Bluteau (v. 6, p. 326).

49. Ver: Inventários $e$ testamentos... (v. 5 p. 235248; 275-300).

50. Ver John Manuel Monteiro (1994) e Luiz Felipe de Alencastro (2000, p. 117-154;188-246).

51. Cf. Luiz Felipe de Alencastro (2000, p.194195). havia certa variedade desses elementos materiais da cultura: foram identificados 32 tipos de peças de roupa, em diversos tecidos. Algumas dessas, especialmente as mais requintadas, conforme as descrições nos inventários, eram importadas de diversos lugares.

De acordo com John French, produtos provenientes de diversas regiões do globo, como objetos de metal da Espanha, roupas de Londres, Flandres e Holanda, ferramentas da França, sal e vinho de Portugal, tecidos e louças da Índia, por exemplo, chegavam a São Paulo, mostrando que o comércio mundial alcançava até os locais mais remotos. Segundo o autor, essa relação com o mercado colonial e mundial era bastante importante para os paulistas, que mesmo produzindo para subsistência, sentiam-se tentados a vender o excedente de suas safras para adquirirem artefatos importados de luxo e prestígio. Nessas transações, certo número de comerciantes intermediários atuava nas duas direções: levando os produtos paulistas e trazendo os importados ${ }^{44}$.

Nos inventários e testamentos, a diversidade de proveniências dos artefatos é bastante perceptível nas descrições de tecidos, alfaias e peças de roupas. Tais indicações podem ser tomadas como indícios das conexões comerciais do império ao redor do globo, mas também evidenciam a inserção de São Paulo nesse conjunto de relações. No inventário de Gaspar Barreto, falecido em 1629, por exemplo, constam duas toalhas de pano do reino. Gaspar possuía uma ampla lista de devedores, tanto na vila quanto no Rio de Janeiro. Em seu testamento, declarou deixar ao seu irmão Francisco Barreto vinte mil réis em farinhas de trigo postas em Santos ${ }^{45}$.

No inventário de Maria da Silva, falecida em 1616, havia registro de um corpinho de cetim flamengo lavrado. Maria era casada com Cláudio Forquim, ourives e comerciante. Entre os devedores do casal estava Francisco de Mariz, do Rio de Janeiro. Constava também que Cláudio devia sessenta mil réis a Ortiz da Fonseca, biscainho ${ }^{46}$, de fazenda que the deu para vender ${ }^{47}$. No rol de bens de Marina de Chaves, falecida em 1617, constava uma toalha de mesa de Flandres. No de Isabel Sobrinha, falecida em 1619, havia um pavilhão ${ }^{48}$ de pano da Índia branco e adamascado, uma saia de raxa florentina e um calçado de Valença (chapins) ${ }^{49}$.

que possibilitava, em certo grau, a prática do comércio de longas rotas pelos paulistas e, conseqüentemente, a presença de artefatos dessa natureza em seus patrimônios era a existência de cativos indígenas aproveitados no transporte de $\operatorname{cargas}^{50}$. Conforme apontou Luiz Felipe de Alencastro, São Paulo desenvolvia-se como provedor de alimentos para as outras partes da América portuguesa e Angola, as quais importavam da vila produtos como farinhas "de mandioca e de trigo, milho, feijão, carnes salgadas, toucinho, linguiça, marmelada, tecidos rústicos e gibões de algodão a prova de flechas" ${ }^{\prime \prime}$. Todos esses desciam a serra do mar, sendo carregados por índios, da mesma forma que os importados subiam para o planalto. Além disso, São Paulo encontrava-se numa posição favorável. Conforme muitos autores apontaram, a vila situava-se no entroncamento 
de uma densa rede de caminhos que conectavam as regiões litorâneas ao interior. As rotas que se estendiam pelo sertão alcançavam longínquos lugares, como o Guairá e outras cidades e vilas castelhanas, como Assunção, por exemplo52.

Cabe assinalar que nem todos os inventários do período portam registros de peças de roupas. De 130 documentos, em 16 não havia registro de avaliação de artefatos da categoria vestimentas, ou seja, 12,3\% da amostra. Esse índice merece observação atenta. Todas as pessoas deveriam possuir alguma peça de roupa, tendo em vista a necessidade de cobrir o corpo nessa sociedade e as funções de distinção assumidas pelas vestimentas no contexto. A margem de ausência dessa categoria de bens nos inventários poderia ser indicativa de diversas possibilidades. Cabe lembrar o fato de que muitos ocultavam bens no momento de se realizar o inventário, fosse do cônjuge ou de outro familiar com o qual se dividia o espaço domiciliar. Essa prática ilícita certamente distorce os números analisados.

Dentre os 16 inventários marcados pela ausência de roupas, 3 tiveram monte-mor acima de cem mil réis. Cremos que esses casos corroboram a possibilidade de ocultação.

No inventário de Gaspar Barreto, falecido em 1629, o patrimônio avaliado somou $1.224 \$ 125$ (um conto, duzentos e vinte e quatro mil, cento e vinte e cinco réis), incluídas as dívidas que the eram devidas por mais de oitenta pessoas da vila. Sem os créditos, o monte-mor da fazenda de Gaspar somaria 237\$510 (duzentos e trinta e sete mil, quinhentos e dez réis), valor que se encontraria entre os patrimônios abastados da vila, na época. Ele possuía casa na vila, de dois lanços, com corredor e quintal e uma casinha no quintal, a qual era equipada com móveis variados, entre os quais 4 caixas, duas grandes, de sete palmos e duas pequenas, de cinco palmos e meio, quatro cadeiras de estado, dois bufetes e uma alcatifa; utensilios, entre os quais estavam colheres e um copo de prata; alfaias variadas, entre as quais se encontravam cinco toalhas de mesa, um travesseiro de pano de linho com sua almofadinha, dois lençóis de algodão, seis guardanapos e uma toalha de mão. Além disso, tinha mais uma casa velha na vila, um sítio, na região do Forte, com casa de três lanços de taipa de mão, com corredor e coberta de telhas, uma casa de pedra e cal na vila de Santos, gado bovino e suíno, mais escravos negros africanos. Apesar do registro de grande fortuna, não consta sequer uma peça de roupa no inventário. Soa um tanto estranho que alguém com uma extensa rede de devedores, provavelmente um mercador, que negociava com tantas pessoas se apresentasse em trapos ou no hábito de Nossa Senhora do Carmo, com o qual pediu para ser enterrado ${ }^{53}$.

Para além da ocultação de objetos, é necessário considerar outras hipóteses. Cada habitante acumulava poucas peças para o uso cotidiano. Ao falecerem, muitos eram enterrados com as roupas que possuíam, daí o não registro desses itens nos inventários. Dentre os 16 inventários sem registro de roupas, 7 apresentavam monte-mor menor do que a quantia de cinquenta mil réis. Isabel de Moraes, falecida em 1630, teve registrado em seu inventário apenas gado, somando quatorze mil e quatrocentos réis. Braz de Pinha, falecido no mesmo ano,
52. Sobre os caminhos que se prolongavam de São Paulo rumo ao litoral e ao interior, ver Sergio Buarque de Holanda (1994, p. 19-35); John Manuel Monteiro (1994, p. 57-98); Ilana Blaj (2002, p. 157-208) e José Carlos Vilardaga (2010, p. 189-280).

53. Ver Inventários $e$ Testamentos... (v. 8, p. 2390). 
possuía uma casa pequena na roça, ferramentas de lavoura (foices e enxadas) para lidar em seu pedaço de roça, uma caixa, três vacas, nove porcos, algumas peroleiras vazias e dois pratos, uma arroba e meia de algodão e duas de carne de porco. Tudo somava cerca de vinte e um mil réis.

As fazendas cujos monte-mores somavam quantias abaixo de cem mil réis geralmente apresentavam objetos e bens estreitamente ligados à sobrevivência, sendo escassos bens representativos de luxo ou status como na fazenda de Braz de Pinha, acima mostrada, composta por bens de raiz (casas, roças, terrenos, etc.) marcados pela simplicidade e tamanho reduzido - poucas ferramentas, apenas um móvel (a caixa), pouco gado, escassos utensílios da casa (peroleira e pratos) e alguma reserva de alimento, que poderia ser consumido no âmbito do domicílio, ou ser trocado com vizinhos. Nota-se a ausência de alfaias (ou seja, roupa branca da casa, como lençóis, cobertores, toalhas, etc.), de utensílios de prata (como colheres, copos ou jarras) ou louças da Índia, e mesmo de móveis de tipos variados (cadeiras, mesas, bufetes, camas, etc.). Dos 130 inventários trabalhados 68 tinham monte-mor abaixo de cem mil réis, ou seja 52,3\% da amostra.

A partir de cem mil réis nota-se uma diversidade maior de artefatos e em alguns casos, os referidos artigos de luxo. A casa começa a apresentar mais utensílios (o número de pratos aumenta, bem como o de bacias, gamelas, tachos de cobre, colheres e facas, castiçais, entre outros) e alfaias (toalhas de mesa ornamentadas, toalhas de mão e de rosto, guardanapos, lençóis de tecidos variados e importados, cobertores, etc.) que garantem comodidade aos seus habitantes. Dos 130 inventários trabalhados, 33 apresentaram monte-mor entre cem mil e um réis e duzentos mil réis, ou seja, 25,3\% da amostra. Já nos patrimônios acima de duzentos mil réis, é constante a presença de artefatos de prata, rouparia da casa de linho e outros tecidos refinados (alfaias importadas e/ou ornamentadas), grande variedade de móveis, extensos conjuntos de ferramentas para o exercício de várias atividades e ofícios simultaneamente. Dos 130 inventários trabalhados, 29 apresentaram monte-mor acima de duzentos mil réis, ou seja 22,3\% da amostra. É importante notar que mesmo nos inventários mais pobres há presença de indígenas, declarados como peças forras ou serviços obrigatórios.

De maneira geral, ao longo do período que se estende entre 1596 e 1640, a maioria dos patrimônios tinha de 0 a 5 \% de sua composição em roupas: 59 de 130, ou seja, 45\% da amostra; 32 tinham de 5, 1\% a 10\%, ou seja, 24,6 \% da amostra; 21 tinham de 10,1\% a 15\%, ou seja, 16\% da amostra e os outros 18 restantes tinham mais de 15,1\% de sua composição em roupas. É necessário pontuar que em 13 dos 18 casos em que o percentual de roupas no patrimônio superava $15 \%$ os monte-mores eram menores do que cem mil réis. Nos outros 5 casos, o que se observa é uma grande quantidade de roupas, ou a presença de itens caros de luxo. Compreendemos por peças de luxo aquelas que, não apenas raras, eram valiosas e carregavam signos de distinção, fosse pela dificuldade de acesso a essas peças, ou pela sua origem diferenciada, ou mesmo pelas matérias- 
primas empregadas em seu feitio. Ou seja, eram itens aos quais poucos tinham acesso e que garantiam a seus donos ostentar uma posição social diferenciada pelo seu uso ${ }^{54}$.

Catarina de Pontes, falecida em 1621, é o exemplo mais claro de uma arca que guardava uma combinação de artigos de luxo com artigos comuns. Catarina era casada, na época de sua morte, com Pero Nunes. $\bigcirc$ conjunto de roupas do casal alcançou a cifra de $87 \$ 300$ (oitenta e sete mil e trezentos réis), compondo $24,3 \%$ do monte-mor.

Catarina e Pero viviam num sítio, localizado no lpiranga, com uma casa de dois lanços, de taipa de mão coberta de telhas, e outra de palha, cercada de parreiras, com limeiras, laranjeiras, pacoveiras e duas restingas de alimentos. Esse conjunto de bens de raiz fora avaliado em vinte e um mil réis. Além desses, havia outras roças e replantas e um canavial. Havia 39 índios, descritos como gente de serviço. Para o trabalho deles, ferramentas de lavoura e de mineração, uma prensa e um alambique. $\bigcirc$ casal possuía também 50 cabeças de gado, um casal de equinos, equipados com sela, estribeiras e freios, 45 cabeças de gado suíno, galinhas e perus.

No interior da casa, ampla utensilhagem doméstica: 14 pratos, um prato de água para as mãos, um jarro, um saleiro, tudo de estanho; em prata, havia um jarro e seis colheres, que perfaziam a quantia de seis mil, setecentos e quarenta réis. Quanto aos móveis da casa do sítio, não consta variedade: taboas de mesa sem pés e uma rede nova lavrada com franja, esta última avaliada em dois mil réis. Em alfaias havia certa variedade: seis toalhas de mesa de algodão, algumas ornamentadas com franjas, três toalhas de mão e onze guardanapos. Havia também outra casa, na vila, de três lanços, taipa de pilão, com repartimentos de taipa de mão e quintal, avaliada em vinte mil réis. Nessa casa, os móveis eram mais variados: duas caixas de cedro com fechadura (uma mais nova, alcançou o preço de dois mil réis, a outra foi avaliada em mil duzentos e quarenta réis); uma mesa (oitocentos réis); oito cadeiras de estado (juntas valiam cinco mil cento e vinte réis); dois colchões cheios de erva, dos quais se avaliou apenas o pano (mil duzentos e oitenta réis). As alfaias também: cortinas (seis mil réis); um lambel ${ }^{55}$ (quinhentos réis); quatro guardanapos (cento e sessenta réis); cinco lençóis usados de pano de algodão (cinco mil réis); meio travesseiro de pano de algodão (trezentos e vinte réis) e um cobertor usado (mil réis).

No rol de bens foram declaradas muitas roupas do casal. Dele, havia três camisas de homem (novecentos e sessenta réis); ceroulas de pano de algodão novas (quatrocentos réis); duas ceroulas de pano de algodão velhas (quatrocentos réis); um ferragoulo de baeta preta de homem ainda novo (três mil e seiscentos réis); roupeta de baeta usada (dois mil réis); roupeta e calções de pano azul já usados (três mil e quinhentos réis); um gibão de telinha branca, já usado (seiscentos e quarenta réis); vestido roxo composto por capa, calções e roupeta (não avaliado), estava sendo usado pelo inventariante ao se fazer as declarações, ficando, pois, de fora da partilha.
54. Pensamos o luxo da mesma perspectiva adotada por Fernand Braudel (1995, v.1, p.161-164), ao analisar os elementos da vida material que integravam o supérfluo e o costumeiro no cotidiano.

55. Pano grosso de lã, geralmente listrado de várias cores, que servia para cobrir bancos (alambel). Ver Raphael Bluteau (17121728 , v. 5 , p. 26 ). 
56. Burato - pano de seda fina, geralmente empregado na feitura de mantos. Melcochado - seda de furtacores. Bombazina - fustão, pano de algodão. Azeitonado - de cor de azeitona. Raxeta - pano de lã grosseiro, estreito e imprensado, no qual não ficam pelos, de várias cores. Chapins - calçado de quatro ou cinco solas de cortiça, usado pelas mulheres para parecerem mais altas. Ver Raphael Bluteau (17121728 , v.2, p. 209 ; v. 9 , p. 32 ; v. 4 , p. 242 ; v. 1 , p. 693 ; v. 7, p. 123 ; v. 2 , p. 276).

57. Ver Inventários e Testamentos... (v. 5, p. 419466).

58. Marco Aurélio Drumond constatou em seu estudo Indumentária e Cultura Material: produção, comércio e usos na Comarca do Rio das Velhas (17111750), que a camisa de algodão era um item básico da indumentária feminina nas Minas Gerais do Século XVIII, a qual era combinada com saias e mais ornamentos como fitas, brincos, anéis, etc. Ver Marco Aurélio Drumond, (2008, p. 125).

59. Cf. Inventários $e$ Testamentos... (v. 1, p. 25).

60. Tecido de lã, fiado ao tufo. Ver Raphael Bluteau (1712-1728, v. 3, p. 306).

61. Pano da Índia, pintado de cores em listras e ramos, semelhante às chitas. Ver Raphael Bluteau (v. 8, p. 235).

62. Ver Inventários $e$ Testamentos... (v. 7, p. 361369).
Dela, havia um manto de sarja (três mil réis); um manto de burato (dez mil réis); um saio e uma saia de melcochado preto, o saio com dois colchetes de prata dourados, macho e fêmea (vinte e cinco mil réis - note-se o valor maior que o do sítio e o da casa da vila); saio e saia de tafetá azul (nove mil réis); gibão de tafetá da Índia, já usado (oitocentos réis), um gibão de tafetá preto novo (três mil réis); gibão de bombazina listrado já usado (mil, duzentos e oitenta réis); corpinho de malha de cetim guarnecido de cetim azul (novecentos e sessenta réis); corpinho de tritaina (seiscentos e quarenta réis); outro corpinho do mesmo material, já usado (quatrocentos réis); um manto de saria, velho (mil e seiscentos réis); saia de pano azeitonado, já usada (três mil réis); saia de raxeta florentina, nova, com três espiguilhas verdes (dois mil e quinhentos réis); saia de pano fino azeitonado com uma barra de veludo verde (cinco mil réis); saia de Londres azul, nova (cinco mil e quinhentos réis); saio de baeta velho (mil duzentos e oitenta réis); uma cinta vermelha, usada (quatrocentos réis); chapins de Valença, usados, com sapatas novas vermelhas (mil réis); quatro camisas de mulher, já usadas, com cabeções de pano de linho, uma camisa de pano de algodão e fraldas de pano de algodão (dois mil duzentos e quarenta réis) ${ }^{56}$.

Catarina tinha quatro filhos: um do primeiro casamento e três com Pero Nunes. As roupas das crianças não foram avaliadas, mas entregues ao pai para vestir os menores ${ }^{57}$.

exemplo acima nos indica, entre outras coisas, os altos preços que as roupas alcançavam nas avaliações feitas nos processos inventariais. Mas, apesar disso, é necessário observar que Catarina possuía uma quantidade grande de roupas, em comparação com as outras mulheres do período, bem como itens importados e outros feitos de tecidos nobres. Uma quantia de artefatos desse tipo era privilégio de poucas mulheres na vila São Paulo no século XVII. A maioria contava apenas com camisas simples, sem ornamentos, de algodão da terra e saias do mesmo pano ou, em alguns casos, de baeta ou raxeta, sem ornamentações ${ }^{58}$.

Não cremos que as condições das roupas, no período estudado, se velhas ou rasgadas, impedissem que fossem inventariados. Afinal, em diversos casos esses artefatos foram registrados nessas situações, como veremos a seguir.

No inventario de Pero Leme, falecido em 1600, constam diversas peças de roupas, dentre as quais foram registrados "dois chapéus velhos", "um manto de sarja velho podre", "um gibão de pano preto muito velho"59. Já no rol de bens de Diogo de Souza, morto sem testamento em 1628, constava calção e roupeta de estamenhabo parda (avaliados em oitocentos réis), meias velhas pretas de seda (cento e vinte réis), um chapéu velho (trezentos e vinte réis), um gibão de taficirabl (seiscentos e quarenta réis), um catre, que era seu objeto mais valioso (mil cento e vinte réis), sapatos de homem de cordovão (duzentos réis) e uma tesoura (quatrocentos réis) ${ }^{62}$. $\bigcirc$ gibão de taficira, registrado entre as vestes do defunto, não era seu. Ele havia tomado por empréstimo a peça de Bernardo de Sanches, que permitiu que fosse lançada em inventário "por não querer aceitar de princípio 
entendendo que tho pagassem porquanto estava danificado por o trazer vestido o dito defunto e o matarem com ele vestido"63.

Podemos observar que itens danificados eram inventariados, às vezes sem constar qualquer menção à avaria. Afinal, uma roupa possivelmente rasgada e manchada de sangue fora inventariada e levada a leilão. Nota-se, também, que roupas circulavam entre conhecidos por meio de empréstimos.

As descrições desses artefatos nos inventários variavam bastante, no que diz respeito à sua apresentação. Conforme aumentava a sofisticação e o luxo da peça de vestimenta, mais detalhes eram fornecidos e registrados, bem como aumentava o preço estabelecido nas avaliações. Das camisas, usadas por homens e mulheres, bastante comuns, na maioria dos casos feitas de tecido de algodão da terra, passava-se às saias com barras bordadas ou em veludo, adornadas com colchetes de prata sobredourada, fitas e passamanes, feitas em tecidos finos, provenientes do Reino, de Londres ou de outras regiões europeias. As peças ricamente ornamentadas ou compostas de tecidos refinados alcançavam altas cifras, que equivaliam ou superavam o preço de outros bens como casas, sítios e roças. Como no exemplo de Catarina de Pontes, acima apresentado.

Antonia de Chaves, falecida em 1610, um outro exemplo, possuía um pequeno algodoal avaliado em mil réis. A única peça de roupa registrada em seu inventário, uma vasquinha ${ }^{64}$ de pano do reino, alcançou a cifra de mil e quinhentos réis, ultrapassando o referido bem de raiz ${ }^{65}$. A casa da defunta, de taipa de pilão, com dois lanços, coberta de telhas, com seus chãos e quintais, valia dez mil réis. A saia representava 15\% do valor da casa ${ }^{66}$. No inventário de Gonçalo da Costa, falecido em 1599, consta "um sítio, com casas de palha e quintal de marmeleiro", avaliado em dois mil e quatrocentos réis. Uma saia de tafetá azul de sua esposa Agueda, falecida na mesma época de Gonçalo, foi avaliada no mesmo valor ${ }^{67}$.

Os altos valores atribuídos às peças de roupas no período estudado, em comparação com outros bens, indicam sem dúvida a importância desses artefatos, especialmente num contexto de abastecimento irregular de produtos provenientes do reino.

Como afirmou Marco Aurélio Drumond, a indumentária do português caracterizou-se, desde muito cedo, pela incorporação de tecidos, cores, modelos e ornamentos provenientes das diversas regiões com que Portugal mantinha vínculos comerciais. Assim, a vida cortesã de vários pontos da Europa influenciava a sociedade portuguesa no que tangia às primeiras transformações do consumo efêmero relativo a artigos de luxo e moda, ainda no século XVI|68. De acordo com Braudel, na Europa ocidental da Idade Moderna a moda, em seu funcionamento, tinha difusão bastante lenta, ligada a mecanismos e a pressões ${ }^{69}$. As preponderâncias políticas, segundo o historiador, não afetariam imediatamente o universo das modas. Haveria descompassos, lacunas, lentidões e aberrações.

No ambiente da América portuguesa, especificamente em São Paulo, no período estudado, as modas pareciam circular mais lentamente do que na
63. Cf. Idid. (p. 366).

64. Saia com muitas pregas.

65. Ver Raphael Bluteau (1712-1728, v. 8, p. 372).

66. Ver Inventários $e$ Testamentos... (v. 1, p. 7072).

67. Cf. Inventários $e$ Testamentos... (v. 1, p. 283306).

68. Ver Marco Aurélio Drumond (2008. p. 100).

69. Ver Fernand Braudel (1995, p. 291). 
70. Sobre a questão das modas características de cada região europeia e as influências que trocavam entre si, ver Carl Köhler (2009); François Boucher (2010, p. 153-256) e James Laver (1989, p. 74-125).

71. Luiz Gonzaga da Silva Leme (1903-1905, v. 8, p. 445).

72. Talim ou cinturão em que se trazia a espada a tiracolo. A ferragem dessa peça seria uma fivela usada para o fechar em volta do corpo. Ver Raphael Bluteau (1712-1728, v. 8, p. 18)

73. Ver Inventários $e$ Testamentos... (v. 11, p.137265). Os legados doados aos filhos legítimos não constavam no testamento, que possuía trechos ilegíveis. Encontramos a informação em meio às demandas e querelas surgidas no processo de partilha.
Europa $^{70}$. Evidência disso seria o fato de que, às vezes, as roupas eram passadas de pais e mães para filhos e filhas, de tios e tias para sobrinhos e sobrinhas, ou para outros parentes e amigos, como se vê por meio do estudo dos testamentos.

Luiz Furtado, morador na região de Urubuapira, termo da Vila de São Paulo, era irmão de Leonel Furtado, que foi o tronco da família Furtado citada na genealogia de Silva Leme ${ }^{71}$. Ao testar, em 1636, mesmo ano em que falecera, legara peças de seu vestuário aos seus três filhos, Luis Furtado, de 17 anos, Pero Furtado, de 16 anos, ambos filhos legítimos tidos com a segunda mulher, e Manuel, filho bastardo tido de uma moça solteira do gentio da terra.

A Manuel, mameluco, Luis deixou uma esmola no valor de dez mil réis em dinheiro e um vestido usado de pano verde composto por roupeta e calção. $\bigcirc$ vestido, já envelhecido pelo uso, fora avaliado no inventário por dois mil e quinhentos réis.

Os outros dois filhos receberam peças que, apesar de não avaliadas em inventário, cremos serem de alto preço. Pelo legado do pai, Luiz recebeu um vestido de baeta usado, um rapaz da terra, uma espada, cinto e talabarte ${ }^{72} \mathrm{com}$ ferragem de prata. Pero, por sua vez, ganhou um rapaz da terra, um ferragoulo e roupeta de baeta nova ${ }^{73}$. Roupas, peças escravas e armas foram legadas aos filhos pelo pai. Tanto as vestimentas quanto a propriedade de peças escravas eram elementos que contribuíam para tornar visível e definir o lugar do indivíduo na sociedade. Já as armas, além disso, eram necessárias para o apresamento dos índios e para as atividades ligadas à guerra.

Manuel não pôde desfrutar dos benefícios do legado herdado. Em 1637, Leonel Furtado, irmão do falecido e nomeado curador dos órfãos, procurou - juiz para saber o que deveria fazer com a esmola a ser entregue a Manuel, pois - garoto havia falecido. Ele desejava, também, ser ressarcido do dinheiro que havia gastado com o menino, provavelmente em seu período de doença. $\bigcirc$ ouvidor geral da repartição sul, tomando ciência do caso, ordenou a Leonel que entregasse o dinheiro à mãe do garoto, ou aos parentes mais chegados. Luiz Furtado, filho de Cosma Mendes, também não teve boa sorte. Foi assassinado em uma viagem ao sertão. Sua mãe, em 1638, requereu ao juiz que mandasse o curador Leonel entregar-the os bens que pertenciam a Luiz, pois era a única herdeira dele.

Em 31 testamentos de uma amostra composta de 179, escritos entre 1590 e 1640, pudemos acompanhar a expressão de vontades que envolviam a entrega de roupas e joias a pessoas específicas. Esse volume seria indicativo da frequência com que ocorria esse tipo de transmissão, pelas cláusulas de últimas vontades. No entanto, cabe frisar que nos processos inventariais, ao serem realizadas as partilhas, as roupas dos defuntos eram, às vezes, entregues aos seus herdeiros, caso a estes fosse possível usá-las. Se os herdeiros fossem menores, as roupas eram levadas à praça para serem leiloadas, fossem peças comuns ou de luxo.

Nos leilões de bens de órfãos, realizados semanalmente na vila de São Paulo, as roupas geralmente eram vendidas facilmente, às vezes alcançando cifras 
maiores do que as estabelecidas pelas avaliações. $\bigcirc$ vestido que pertencera a Baltazar Alves, falecido em 1613, composto de roupeta e calções de raxeta verde, foi avaliado em dois mil e quinhentos réis, suas duas camisas novas de algodão, em novecentos réis, e uma ceroula de algodão, em trezentos e vinte réis. Tal conjunto de peças, arrematado pelo valor de quatro mil réis, foi pago no ato da compra por Antonio Telles, que veio a ser juiz dos órfãos alguns anos depois ${ }^{74}$. Quando a roupa colocada a leilão era muito velha, os compradores não mostravam interesse, ficando a peça encalhada no baú dos órfãos. Em alguns casos, itens desgastados acabavam sendo vendidos pelo mesmo preço estabelecido nas avaliações. De qualquer forma, os leilões colocavam em circulação muitos tipos de artefatos, como móveis, ferramentas, utensílios da casa e outros, dentre os quais as roupas se destacavam.

No inventário de João do Prado, falecido em 1597, no mesmo ano em que escrevera seu testamento, feito na vila, cujo monte-mor somou $285 \$ 190$ (duzentos e oitenta e cinco mil, cento e noventa réis), encontramos algumas peças de roupas: uma camisa nova de pano de linho (avaliada em mil réis); uma camisa de pano de algodão com seus abanos (mil e duzentos réis); uns calções pretos velhos (trezentos e vinte réis); um ferragoulo de pano tosado (dois mil e quatrocentos réis); umas botas (mil réis); chinelas de cortiça novas (trezentos e vinte réis) outras chinelas usadas (duzentos réis). No inventário feito no sertão, havia mais itens dessa categoria de artefatos: calções e roupeta de pano de algodão (quatrocentos réis); uma roupeta de baeta (oitocentos réis); um chapéu preto (quatrocentos réis); botas de veado novas (oitocentos réis); sapatos novos (quatrocentos réis) $)^{75}$.

Sete peças de roupas e cinco pares de calçados pertenciam a este homem. Em nenhuma das vestes constava tecido requintado, com exceção da camisa de linho, a qual valia um pouco menos do que a camisa de algodão com abanos. $\bigcirc$ valor atribuído aos artefatos classificados como vestimentas aumentava não só conforme a natureza da matéria-prima, mas também de acordo com o modelo em questão. Uma camisa simples, mesmo sendo de linho, valia menos do que uma camisa de algodão com abanos, já que a última contava com um adorno que consistia numa espécie de volta com muitas dobras, à moda de canudos, ou ondas ao redor do pescoço ${ }^{76}$. Isso indicaria que o status ostentado pela roupa estaria associado, entre outros elementos, aos modelos portados pelos indivíduos.

Nos dias de missa e procissão os melhores trajes eram usados. Os vestidos de respeito ou trajes de cerimônia costumavam ser mais caros e raros. Como alertou Alcântara Machado, esses exigiam tecidos refinados, como a seda, - gorgorão, a telinha, o tafetá, a chamalote, ou panos finos de linho, lã ou algodão, como a perpetuana, a belbutina, o catasol e outros ${ }^{77}$. Cotidianamente, na vila de São Paulo, usavam-se os vestidos chamados de cote, feitos de tecidos mais simples. No entanto, para circularem em espaços públicos, homens e mulheres selecionavam as melhores peças de suas arcas, caixas ou canastras encouradas e alinhavam sua imagem com muitas cores e tecidos diversificados. A roupa comunicava o posicionamento social do indivíduo, quando este se encontrava em
74. Ver Inventários $e$ Testamentos... (v. 1, p. 309332).

75. Ibid. (p. 77-121).

76. Cremos que a camisa de abanos possua adornos similares ao mantéu de abanos. O significado deste encontra-se em Raphael Bluteau (1712-1728, v. 1, p. 12).

77. Ver José de Alcântara Machado (s/d., p. 96). 
78. Cf. Mary del Priore (1997, p. 319).

79. "Parte superior da vestidura, que cinge o pescoço e se põe a volta, cozida ou abotoada à roupeta ou casaca". Cf. Raphael Bluteau (17121728 , v. 2, p. 10).

80. Ver Inventários $e$ Testamentos... (v. 4, p. 311). meio à multidão. Na vila de Piratininga, o vestuário seria uma forma de ressaltar a origem europeia e diferenciar-se em meio a uma população marcada por grandes contingentes de mamelucos.

A circulação das vestimentas pelas cláusulas de últimas vontades.

Voltemo-nos agora para o nosso principal interesse: a transmissão de roupas por meio de cláusulas de últimas vontades. Segundo Mary del Priore, as preparações para o trespasse possibilitavam um "retrospecto da vida em que se desnudavam as relações sociais e familiares que a tinham marcado"78. Chegava o momento de relembrar aqueles que viveram próximos e recompensar os amigos. Os testamentos, como bem sublinhou a historiadora, refletem com bastante clareza a necessidade de repartir os bens materiais com o cônjuge e com os filhos, assim como demonstram os vínculos com a parentela e com os agregados. A importância que o vestir assumia na sociedade que se formava no planalto na primeira metade do século XVII fazia com que as roupas fossem envolvidas nos desejos de partilhar e legar bens que partia dos moribundos.

Aqui trabalharemos especificamente com os dados obtidos da análise de 31 testamentos nos quais identificamos a transmissão de peças de vestuário, numa tentativa de desvelar os significados que tais legados poderiam atribuir a essas roupas, por meio de breves estudos de caso.

Em 1616, Isabel da Cunha fez seu testamento determinando uma série de legados. Por meio de alguns desses, ela distribuiu suas peças de vestir a diferentes pessoas. Para a mulher que havia sido de João Serrano, Francisca Correia deveria ser entregue uma saia, uma camisa e um gibão, as três peças em pano de algodão. As filhas de Afonso Dias deveriam receber três camisas. Dois cabeções $^{79}$ por fazer deveriam ser doados a mulher de Gaspar dos Reis, Catariana Vaz, sobrinha de Isabel. Messia Sobrinha receberia, em nome da defunta, uma saia velha de raxeta que the pertencera. Francisca e Messia, bem como as filhas do falecido Afonso Dias, possivelmente faziam parte da vizinhança na qual vivia a testadora Para sua neta, Juliana, filha de Henrique da Cunha, ela legava "uma saia de Londres ferrete e saio de baeta e manto e mais o fato do reino" 80 .

$\bigcirc$ conjunto de roupas deixado a Juliana era composto de: um saio de baeta preto guarnecido de tafetá preto (avaliado em dois mil réis); saia de pano azul ferrete (três mil e quinhentos réis); um manto de saria novo (quatro mil réis); um gibão de olanda rajado de preto (quatrocentos réis); um gibão de bombazina roxo guarnecido de tafetá amarelo, para abotoar com seus botões e retrós (mil réis); três pares de chapins de Valença com suas botinas novas (dois mil réis) e um calçado vermelho usado, chapins e botinas (quatrocentos réis).

$\bigcirc$ conjunto doado a Juliana era marcado pela presença de itens de luxo, como o saio preto de baeta, guarnecido de tafetá e o manto de saria novo. Tudo proveniente da Europa, conforme apontara o texto testamentário. No entanto, as esmolas deixadas consistiam em peças comuns, de algodão da terra, ou mesmo 
peças velhas, nas palavras da própria testadora. As camisas doadas eram comuns, de pano de algodão. A testadora possuía sete delas, as quais foram avaliadas em duzentos réis cada uma. A saia e o gibão doados eram de algodão tingido e juntos foram avaliados em quinhentos réis.

Artigos de luxo permaneciam no interior da família, conforme percebe-se na análise de testamentos. Os legados que envolviam doação de roupas a título de caridade colocavam em circulação, para fora do núcleo familiar, apenas os itens mais simples, aqueles empregados no vestuário de cada dia, confeccionados em tecidos da terra ou tecidos baratos ${ }^{81}$. A lógica que parece guiar estas ações estaria vinculada, para além da transmissão de riqueza, ao desejo de manter os signos de status social no interior do circuito composto pelos parentes mais próximos.

caso acima apresentado corrobora a ideia de que as roupas de luxo circulavam por meio das disposições testamentárias apenas no circuito das relações familiares mais próximas ${ }^{82}$. Vestir era algo de fundamental importância na sociedade que se formava em São Paulo, no início do século XVII. A ostentação e a riqueza aparentes, entre outros elementos, funcionavam como mecanismos importantes para manter ou conquistar posições sociais de destaque ${ }^{83}$. E as vestimentas, sem dúvida, eram a principal forma de tornar visíveis os posicionamentos diversos nesta sociedade. Mas, além disso, é importante observar que a doação de roupas por meio de cláusulas testamentárias ultrapassava essa espécie de estratégia para manutenção de um dos meios de ostentação do status da família e traduzia-se simultaneamente em expressões de afeto e/ou preocupações com entes queridos, como veremos por meio do caso a seguir.

Felipa Vicente, falecida em 1615, legou ao único filho que tivera do primeiro casamento "um vestido da parte de minha terça para seu remédio" ao fazer seu testamento ${ }^{84}$. Na época, Paulo tinha 14 anos.

Talvez a mãe se preocupasse em deixar o filho mais velho vestido, visto que para comprar roupas para o menino, o curador teria que dispor de parte de sua legítima. Isso poderia prejudicar Paulo quando alcançasse a maioridade ou fosse emancipado, pois sua herança the garantiria uma base para que pudesse construir seu próprio patrimônio. Pelas contas realizadas no inventário, o quinhão que caberia ao órfão seria de 17\$913 (dezessete mil, novecentos e treze réis), e se tivesse que despender parte dessa quantia com roupas, mesmo que fossem peças simples de algodão, certamente teria gastos significativos, afinal, uma camisa de homem nova, de algodão, custava cerca de setecentos réis, na época. Já uma roupeta nova de pano de algodão, com calções do mesmo tecido, custava cerca de oitocentos réis ${ }^{85}$.

A doação de roupas por meio de cláusulas testamentárias assumia também o caráter de ato de caridade cristã, ou mesmo pagamento de dívidas ou culpas acumuladas em vida.

João Leite faleceu em 1616. Dois anos antes de seu trespasse, ele fez seu testamento, no qual registrou a decisão de doar algumas de suas roupas para os pobres da vila. Ele deixou um ferragoulo de raxeta ao homem mais pobre que
81. Marco Drumond assinala em seu estudo que, por vezes, legar roupas assumia a função de caridade, por meio da qual se buscava acertar as contas com Deus e revelava sentimentos de benevolência, estima, gratidão e reconhecimento. Ver Marco Aurélio Drumond (2008, p. 132).

82. Ver Luciana da Silva (2013, p. 175-224).

83. Milena Fernandes Maranho analisa a maneira como riqueza aparente, crédito e ostentação, em associação com regras de comportamento cortesãs, funcionavam para a manutenção e conquista de privilégios e posições sociais de destaque. Ver Milena Fernandes Maranho (2000, p. 139-163).

84. Cf. Inventários e Testamentos... (v. 3, p. 425).

85. Ibid. (v. 1, p. 132-183 e v. 2, p. 111-199). 
86. Cf. Ibid. (v. 4, p. 477).

87. Pelo estudo que fizemos de 130 inventários, constatamos que em $44,61 \%$ da amostra houve registro de matérias-primas, entre as quais se situavam os tecidos. Os tecidos armazenados mais encontrados foram o algodão, a raxeta e a baeta. Além desses, constaram na documentação: gorgorão, tafetá, olandilha, damasco, damasquinho da Índia, telinha, taficira, ruão, linho, canequim, bocaxim, picote, grise, cassa, serafina, raxa, tiruela, saragoça, burato, melcochado e cordones. Maria Aparecida Menezes Borrego identificou, para o século XVIII, 41 tecidos diferentes nas lojas da vila. Ver Maria Aparecida Menezes Borrego (2006, p. 196-197). se achasse e uma roupeta de baeta "a um homem mais pobre que se achar e seja quem o padre vigário disser" 86 . Além dessas peças, João possuía um ferragoulo de baeta velho, avaliado em quatrocentos réis, e calções pardos forrados de pano de algodão, abotoados pelas ilhargas, que valiam mil e seiscentos réis. $\bigcirc$ ferragoulo de raxeta e a roupeta de baeta não eram, necessariamente, provenientes do Reino, pois era relativamente comum a armazenagem de alguns tecidos ${ }^{87}$. A raxeta e a baeta, ambas feitas com lã, tinham preços relativamente baratos quando comparados com tecidos de seda.

testador desejava que o remanescente da terça fosse entregue à sua mulher, Inês Pedroso, "para que com ela ajude a criar a meus filhos". João instituiu Inês como tutora dos órfãos, Bastião, de 6 anos e João, de 4 anos, e declarou que tinha uma filha bastarda, chamada Isabel, de 8 anos, a qual deixava forra, com o devido consentimento de sua mulher, a qual declarou herdeira. A soma do monte-mor de João alcançou o valor de setenta e três mil e seiscentos réis. Após o pagamento das dívidas, restou para a viúva, referente à sua meação mais a terça, trinta e um mil, setecentos e trinta réis. Cada um dos três órfãos (incluiu-se a filha bastarda na partilha) herdou uma legítima na quantia de cinco mil, duzentos e noventa réis.

As roupas que pertenciam a João Leite eram todas bastante simples, assim como as peças legadas em caridade. Atitudes como essa mostram a preocupação que havia em preparar o caminho para o além, fazendo bem pela própria alma por meio da disposição dos bens materiais. As roupas, que nesse caso passariam a proteger o corpo de algum pobre da nudez e das intempéries, representavam um meio de se alcançar à piedade divina. Apesar de seu patrimônio ser pequeno, João ofereceu em caridade peças que, a despeito de seu provável pouco valor, poderiam acrescentar algo a herança deixada aos filhos, dos quais a criação the preocupava no momento de redigir suas últimas vontades. A crença na necessidade de fazer bem pela própria alma o levou a tal decisão.

Por mais que o temor do que viria após a morte tomasse parte dos pensamentos dos cristãos que viveram entre os séculos XVI e XVIII, suas atitudes nem sempre se alinhavam, durante seus períodos de boa saúde e segurança, com os comportamentos de bom católico que tentavam adotar nos momentos derradeiros. Resultava disso a expressão de muitos arrependimentos e culpas, que muitos tentavam sanar por meio das cláusulas testamentárias.

Este, certamente, foi o caso de Pedro de Araújo, que, andando a risco pelo Sertão de Paraupava, sem saber o que Deus dele faria, decidiu escrever seu testamento no ano de 1616. Talvez no momento certo, pois ele não retornou vivo desta expedição. Em meio às disposições de últimas vontades, o sertanista revelou uma acentuada preocupação com atitudes que tivera em relação a sua enteada, Maria, filha de sua mulher Ana de Alvarenga.

Tendo acesso aos bens da menina, Pedro vendeu uma índia que the pertencia pelo valor de vinte e cinco mil réis, quantia que não repassou à enteada. $\bigcirc$ padrasto também tomou três mil e quatrocentos réis da legítima que o pai deixara a garota. Entretanto, em seu testamento, o homem reconheceu sua conduta errada 
em relação à filha de sua esposa e pediu que os valores fossem tomados em sua terça para o ressarcimento de Maria. Mais do que isso, o testador declarou que, se houvesse terça suficiente, doze mil réis deveriam ser entregues a sua enteada para ajudar na compra de um vestido 88 .

Vestir bem a enteada poderia significar a obtenção do perdão da menina e a obtenção do perdão divino, além de apontar para o desejo de proteger a herança da enteada dos gastos com vestimentas. Mais do que isso, poderia indicar o cumprimento de uma obrigação relativa aos deveres de um padrasto que toma o lugar de pai. Vestir os órfãos de acordo com sua condição, ou seja, de acordo com sua posição social, era uma das atribuições que os juízes cobravam daqueles que, no lugar do pai falecido, comprometiam-se a criar crianças desamparadas pela morte de seu genitor. Infelizmente, a terça de Pedro não foi suficiente para cumprir esses desejos...

\section{Considerações finais}

Os trajes, na vila de São Paulo e arredores, entre as décadas finais do século XVI e primeira metade do XVII, variavam de acordo com o posicionamento social do indivíduo. A maior parte da população acumulava poucas peças de vestuário. Vestir-se com luxo dependia do poder aquisitivo do indivíduo e de sua família. Afinal, as peças de roupa, bem como os tecidos mais refinados, eram caros e inacessíveis à maior parte da população, que empregava mormente tecido de algodão tinto na confecção de suas vestes. Mesmo as roupas de algodão eram utilizadas juntamente com peças de luxo, diferenciando-se do vestuário modesto pelos modelos e ornamentos que the enfeitavam. Mas, de maneira geral, aqueles que possuíam fazenda para ostentar por meio da indumentária, usavam das peças de tecido de algodão apenas nas roupas interiores, como ceroulas e camisas, no caso dos homens, ou as fraldas (saias utilizadas por baixo das vestes). As roupas eram fundamentais para se ostentar uma determinada posição social.

Ao testar, todos estes elementos pesavam muito nas decisões dos testadores. Roupas de luxo permaneciam no circuito familiar mais próximo pelas vontades estabelecidas nos testamentos. Mesmo quando as roupas de um indivíduo eram postas em circulação após sua morte pela força de seus legados caritativos, essa lógica não era abandonada: doavam-se as peças mais simples do vestuário, de tecido de algodão ou de tecidos baratos, quando não peças envelhecidas. Até os mais pobres não dedicavam suas melhores vestes à caridade. Afinal, o valor das peças de roupa era bastante alto e em meio às preocupações concernentes a uma boa morte encontravam-se àquelas referentes à necessidade de deixar amparados os familiares, por meio da boa disposição dos bens materiais. A doação de vestes por meio dos testamentos também assumia o caráter de legado caritativo. Vestir os pobres, ou dar a eles um artefato que, se vendido lhes renderia algum dinheiro, também representava uma forma de assumir um comportamento cristão, angariando a piedade divina.
88 Ver Inventários $e$ Testamentos... (v. 5, p. 173214). 


\section{REFERÊNCIAS}

\section{FONTES IMPRESSAS}

Inventários e Testamentos. Papéis que pertenceram ao Primeiro Cartório de Órfãos da Capital. São Paulo: Tipografia Piratininga. v. 1-29.

Inventários e Testamentos. Documentos da Seção do Arquivo Histórico. São Paulo: Tipografia do Globo. v. 30-42.

LEME, Luiz Gonzaga da Silva. Genealogia paulistana. São Paulo: Duprat, 1903- 1905. 9 v. Disponível em: <http://www.arvore.net.br/Paulistana/>. Acesso em 31 out. 2014.

\section{OBRA DE REFERÊNCIA}

BLUTEAU, Raphael. Vocabulário portuguez e latino... Coimbra: Collegio das Artes da Companhia de Jesus, 1712-1728. Disponível em: <http://www.brasiliana.usp.br/en/dicionario>.

\section{LIVROS, REVISTAS E TESES}

ALCANTARA MACHADO. Vida e morte do bandeirante. São Paulo: Imprensa Oficial, 2006.

ALENCASTRO, Luiz Felipe de. O trato dos viventes: formação do Brasil no Atlântico Sul. São Paulo: Companhia das Letras, 2000.

ARIÈS, Philippe. Por uma história da vida privada. In: ARIÈS, Philippe; CHARTIER, Roger (Org.). História da vida privada 3: da renascença ao século das luzes. São Paulo: Companhia das Letras, 1991.

BLAJ, Ilana. A trama das tensões: o processo de mercantilização de São Paulo colonial: 16811721. Tese (Doutorado) - Faculdade de Filosofia, Letras e Ciências Humanas, Universidade de São Paulo, São Paulo, 2002.

BORREGO, Maria Aparecida de Menezes. A teia mercantil: negócios e poderes em São Paulo colonial: 1711-1765. Tese (Doutorado) - Faculdade de Filosofia, Letras e Ciências Humanas, Universidade de São Paulo, São Paulo, 2006.

BOUCHER, François. História do vestuário no Ocidente. São Paulo: Cosac Naify, 2010.

BRAUDEL, Fernand. Civilização material, economia e capitalismo: séculos XV-XVIII: o tempo do mundo. São Paulo: Martins Fontes, 1995. (As estruturas do cotidiano, v. 1).

CALANCA, Daniela. História social da moda. São Paulo: Editora Senac São Paulo, 2008.

DRUMOND, Marco Aurélio. Indumentária e cultura material: produção, comércio e usos na Comarca do Rio das Velhas: 1711-1750. Dissertação (Mestrado) - Universidade Federal de Minas Gerais, Belo Horizonte, 2008. 
FRAGOSO, João; GOUVÊA, Maria de Fátima (Org.). Na trama das redes: política e negócios no império português, séculos XVI-XVIII. Rio de Janeiro: Civilização Brasileira, 2010.

FRENCH, John. Riqueza, poder e mão de obra numa economia de subsistência: São Paulo, 1596-1625. Revista do Arquivo Municipal, São Paulo, ano 45, n. 195, jan./dez. 1982, p. 79-107.

HOLANDA, Sérgio Buarque de. Caminhos e Fronteiras. 3a ed. São Paulo: Companhia das Letras, 1994.

IMÍZCOZ BEUNZA, José María. Comunidad, red social y élites: un análisis de la vertebración social en el Antiguo Régimen. In: . Elites, poder y red social: las élites del País Vasco y Navarra en la Edad Moderna (estado de la cuestión y perspectivas). Bilbao: Servicio editorial, Universidade del Pais Vasco, 1996, p. 13-50.

KÖHLER, Carl. História do vestuário. 3a ed. São Paulo: Editora WMF Martins Fontes, 2009.

LARA, Silvia Hunold. Diferentes e desiguais. In: Fragmentos setecentistas: escravidão, cultura e poder na América portuguesa. São Paulo: Companhia das Letras, 2007, p. 79-125.

PROBERT, Christina. [Capítulo final]. In: LAVER, James. A roupa e a moda: uma história concisa. São Paulo: Companhia das Letras, 1989.

MAGALHÃES, Beatriz Ricardina de. A demanda do trivial: vestuário, alimentação e habitação. Revista Brasileira de Estudos Políticos, Belo Horizonte, n. 65, p. 153-199, jul. 1997.

MARANHO, Milena Fernandes. A opulência relativizada: significados econômicos e sociais dos níveis de vida dos habitantes da região do Planalto de Piratininga: 1648-1682. Dissertação (Mestrado) - Universidade Estadual de Campinas, Campinas, 2000.

MENESES, Ulpiano Toledo Bezerra de. [Prefácio]. In: CARVALHO, Vânia Carneiro de. Gênero $e$ Artefato: o sistema doméstico na perspectiva da cultura material - São Paulo, 1870-1920. São Paulo: Editora da Universidade de São Paulo/Fapesp, 2008, p. 12.

A cultura material no estudo das sociedades antigas. Revista de História: Nova Série, São Paulo, n. 115, p. 103-117, jul./dez. 1983.

MONTEIRO, John Manuel. Negros da terra: índios e bandeirantes nas origens de São Paulo. São Paulo: Companhia das Letras, 1994.

NAZZARI, Muriel. O desaparecimento do dote. Mulheres, família e mudança social em São Paulo, Brasil, 1600 - 1900. São Paulo. Companhia das Letras, 2001.

PAIVA, Eduardo França. Frágeis fronteiras: relatos testamentais de mulheres das Minas Gerais setecentistas. Anuário de Estudios Americanos, Sevilha, v. 66, n. 1, p. 196, janero/junho, 2009.

PESAVENTO, Sandra Jatahy e LANGUE, Frédérique (org). Sensibilidades na história: memórias singulares e identidades sociais. Porto Alegre: Editora da UFRGS, 2007

PRIORE, Mary del. Ritos da vida privada. In: NOVAIS, Fernando A. (Dir.); SOUZA, Laura de Mello (Org.). História da vida privada no Brasil - Cotidiano e vida privada na América portuguesa. São Paulo: Companhia das Letras, 1997. (História da vida privada no Brasil, v. 1). 
REIS, João José. A morte é uma festa: ritos fúnebres e revolta popular no Brasil do século XIX. São Paulo: Companhia das Letras, 1991.

ROCHE, Daniel. A cultura das aparências: uma história da indumentária (séculos XVII XVIII). São Paulo: Editora Senac São Paulo, 2007.

RODRIGUES, Claudia. Nas fronteiras do além: a secularização da morte no Rio de Janeiro. Rio de Janeiro: Arquivo Nacional, 2005.

- Lugares dos mortos na cidade dos vivos: tradições e transformações fúnebres no Rio de Janeiro. Rio de Janeiro: Secretaria Municipal de Cultura, Departamento Geral de Documentação e Informação Cultural. Divisão de Editoração, 1997. (Coleção Biblioteca carioca, v. 43, Série Publicação Científica).

SCARANO, Julita. Roupas de escravos e de forros. Resgate: Revista Interdisciplinar de Cultura, Campinas, n. 4, p. 51-61, 1992.

SILVA, Luciana da. Artefatos, sociabilidades e sensibilidades: cultura material em São Paulo, 1580-1640. Dissertação (Mestrado) - Universidade Estadual de Campinas, Campinas, 2013.

SILVA, Maria Beatriz Nizza da. O trajo. In: Vida privada e quotidiano no Brasil na época de D. Maria I e D. João V. Lisboa: Referência; Editorial Estampa, 1993. p. 227-241.

Sistema de casamento no Brasil colonial. São Paulo: T. A. Queiroz: Editora da Universidade de São Paulo, 1984.

VILARDAGA, José Carlos. São Paulo na órbita do império dos Felipes: conexões castelhanas de uma vila da América portuguesa durante a União Ibérica (1580-1640). Tese (Doutorado) - Faculdade de Filosofia, Letras e Ciências Humanas, Universidade de São Paulo, São Paulo, 2010 . 